\title{
PENERAPAN METODE ASSOCIATION RULE MINING PADA DATA TRANSAKSI PENJUALAN PRODUK KARTU PERDANA KUOTA INTERNET MENGGUNAKAN ALGORITMA APRIORI
}

\author{
Uci Baetulloh \\ Fakultas Teknik, Program Studi Teknik Informatika \\ Universitas Siliwangi \\ Email: ucibaetulloh@gmail.com \\ Acep Irham Gufroni \\ Fakultas Teknik, Program Studi Teknik Informatika \\ Universitas Siliwangi \\ Email: acep@unsil.ac.id \\ Rianto \\ Fakultas Teknik, Program Studi Teknik Informatika \\ Universitas Siliwangi \\ Email: rianto@unsil.ac.id
}

\begin{abstract}
ABSTRAK
Data transaksi penjualan produk kartu perdana kuota internet dapat dijadikan sebagai bahan acuan untuk mengetahui seberapa besar tingkat penjualan produk yang telah dipasarkan oleh beberapa operator telekomunikasi seluler. Data tersebut tidak hanya dijadikan sebagai data arsip penyimpanan laporan penjualan perusahaan saja, tetapi dapat dianalisa dan dimanfaatkan menjadi sebuah informasi untuk membantu dalam melakukan pengembangan strategi pemasaran produk. Tujuan dari penelitian ini yaitu untuk menemukan aturan asosiasi kombinasi antar item produk operator telekomunikasi seluler mana saja yang paling laku terjual di wilayah penjualan Priangan Timur meliputi cluster Ciamis, Garut dan Tasikmalaya. Perhitungan Algoritma Apriori pada aturan asosiasi ini dihitung melalui tiga tahap iterasi pembentukan kandidat k-itemset. Hasil analisa aturan asosiasi yang terbentuk dari perhitungan algoritma apriori dengan menentukan nilai minimum support $35 \%$ dan nilai minimum confidence $80 \%$, menghasilkan 9 aturan asosiasi final terbaik pada cluster Ciamis, 21 aturan asosiasi final untuk cluster Tasikmalaya dan 7 aturan asosiasi final untuk cluster Garut. Ketiga wilayah penjualan tersebut produk yang paling sering laku terjual dipasaran outlet adalah produk dari operator kartu kuota internet XL dengan Telkomsel dan produk Indosat dengan Telkomsel. Hasil penelitian dapat digunakan organisasi untuk pengambilan keputusan dalam meningkatkan penjualan produk yang lebih baik.
\end{abstract}

Kata kunci: algoritma apriori; penjualan; produk kuota internet.

\begin{abstract}
Data on the sale of the initial internet quota card products can be used as reference material to find out how much the level of product sales has been marketed by several cellular telecommunications operators. The data is not only used as archived data for the company's sales report, but can be analyzed and utilized as information to assist in developing product marketing strategies. The purpose of this study is to find the rules of combination associations between items of cellular telecommunication operator products which are best sold in the East Priangan sales area including the Ciamis, Garut and Tasikmalaya clusters. The calculation of the Apriori Algorithm in this association rule is calculated through three iteration stages for the formation of $k$-itemset candidates. The results of the association rule analysis formed from the a priori algorithm calculation by determining the minimum value of $35 \%$ support and $80 \%$ minimum confidence, producing the 9 best final association rules in the Ciamis cluster, 21 final association rules for the Tasikmalaya cluster and 7 final association rules for the Garut cluster. The three sales regions that are the most frequently sold products in the outlet market are products from XL internet quota card operators with Telkomsel and Indosat products with Telkomsel. The results of the research can be used by organizations for decision making in increasing product sales better.
\end{abstract}

Keywords: apriori algorithm; sales; products; internet quota. 


\section{PENDAHULUAN}

Persaingan antara operator telekomunikasi seluler di Indonesia didominasi dan dikuasai oleh penguasa pangsa pasar industri telekomunikasi. Operator telekomunikasi seluler Telkomsel memiliki peredaran berjumlah 178 juta unit produk atau sekitar 45,3\%, selanjutnya diikuti Indosat Ooredoo sebanyak 96,4 juta unit atau 24,54 persen, Tri 56,8 juta unit disusul XL Axiata 50,5 juta unit dan Smartfren 11 juta unit [1].

Wilayah Priangan Timur meliputi daerah Kota/Kabupaten Ciamis, Tasikmalaya dan Garut menjadi salah satu pemasaran dan penjualan produk kartu perdana kuota internet yang masih tetap konsisten dalam memasarkan produknya oleh setiap operator telekomunikasi seluler dalam melakukan pendistribusian serta promosi ke setiap pasar outlet terutama untuk memberikan suatu produk kartu perdana kuota internet dengan harga yang lebih murah dengan jumlah kuota internet yang lebih besar. Dengan kata lain, pihak produsen harus berlomba - lomba menarik minat pelanggan dengan menggunakan berbagai macam bentuk strategi pemasaran agar tidak kalah bersaing dan tetap konsisten dalam setiap pemasaran produknya.

Kemampuan untuk mengambil keputusan yang cepat, tepat dan akurat menjadi kunci keberhasilan dalam menerapkan strategi bisnis yang dapat meningkatkan penjualan dan pemasaran produk yang dicapai. Banyak informasi yang dimiliki namun tidak cukup jika informasi tersebut tidak di manfaatkan dengan sebaik mungkin, ketergantungan akan produk satu dengan produk yang lainnya menjadi dasar utama untuk mengetahui daya saing produk operator mana saja yang memiliki tingkat penjualan yang paling tinggi berdasarkan penjualan yang ada di setiap wilayah Priangan Timur.

Data transaksi penjualan produk kartu perdana kuota internet dapat dijadikan sebagai bahan acuan untuk mengetahui seberapa besar tingkat penjualan produk yang telah dipasarkan oleh beberapa operator telekomunikasi seluler. Data tersebut tidak hanya dijadikan sebagai data arsip penyimanan laporan penjualan perusahaan saja, tetapi dapat dianalisa dan dimanfaatkan menjadi sebuah informasi untuk membantu dalam melakukan pengembangan strategi pemasaran produk. Hal ini tentunya dibutuhkan suatu aplikasi yang dapat melakukan analisa terhadap data transaksi penjualan kartu perdana kuota internet. Salah satunya yaitu dengan menerapakan metode Association Rule Mining menggunakan perhitungan Algoritma Apriori.

Penerapan Association rule mining (aturan asosiasi), yaitu teknik data mining untuk menemukan aturan asosiasi suatu kombinasi item yang tersembunyi dalam database [2]. Hal ini dapat membantu untuk menemukan aturan asosiasi antara suatu kombinasi item produk kartu perdana kuota internet yang paling banyak laku terjual secara bersamaan dengan produk operator lainnya.

Aturan asosiasi sendiri terdapat beberapa penggunaan algoritma diantaranya menggunakan, algoritma $f p$ - growth, algoritma apriori, algoritma fuzy c-covering, dan algoritma hash-based dimana masing-masing algoritma memiliki berbagai kelebihan dan kekurangan [3]. Algoritma apriori, menurut beberapa peneliti termasuk salah satu algoritma yang banyak digunakan tahap analisis asosiasi untuk menghasilkan algoritma yang efisien dalam analisis pola frekuensi tinggi [4]. Salah satunya penelitian yang dilakukan oleh Ristianingrum dan Sulastri menjelaskan tentang analisis data transaksi penjualan untuk membantu menghasilkan pola transaksi dari konsumen, sehingga hasilnya dapat diketahui informasi produk dan jasa apa saja yang sering muncul dan diminati konsumen dengan mengimplementasikan data mining menggunakan algoritma apriori [5].

Dua tolak ukur untuk mengetahui pentingnya suatu asosiasi dapat diketahui, yaitu support dan confidence. Support atau nilai penunjang merupakan persentase kombinasi item dalam database, sedangkan confidence atau nilai kepastian adalah kuatnya hubungan antar-item dalam aturan asosiasi. Dari dua tolak ukur tersebut maka algoritma apriori dapat digunakan untuk membantu pengembangan strategi pemasaran [4].

Berdasarkan uraian masalah diatas, maka maksud dan tujuan penelitian ini yaitu menerapkan metode association rule mining menggunakan algoritma apriori untuk melakukan analisa terhadap data transaksi penjualan produk kartu kuota internet yang diimplementasikan pada aplikasi yang dibangun. Hal ini untuk mempermudah dalam melakukan analisa terhadap daya saing produk operator telekomunikasi seluler mana saja yang memiliki tingkat penjualan produk yang paling laku terjual secara bersamaan dengan produk operator lainnya. Dengan demikian hasil yang diperoleh dapat digunakan untuk membantu pengambil keputusan dalam meningkatkan pemasaran dan promosi produk yang lebih baik.

\section{METODOLOGI PENELITIAN}

Metodologi penelitian merupakan langkah untuk memperoleh data untuk diproses menjadi informasi yang lebih akurat dan sebagai pedoman dalam pelaksanaan penelitian agar hasil yang dicapai tidak menyimpang dari tinjauan yang dicapai. Ada empat tahapan yang dilakukan untuk menyelesaikan pada penelitian tugas akhir ini diantaranya: pengumpulan data, identifikasi terhadap penerapan metode association rule mining menggunakan algoritma apriori, pengembangan sistem dan pengujian. 


\subsection{Pengumpulan Data}

Pengumpulan data dilakukan dengan melakukan observasi pengamatan langsung ke tempat penelitian di PT. Telkomsel Branch Tasikmalaya Jawa Barat untuk memperoleh informasi data yang dibutuhkan dalam penelitian, kemudian melakukan wawancara tanya jawab langsung kepada pihak pimpinan dari Divisi Boradband and Digital Sales PT. Telkomsel Branch Tasikmalaya terkait tentang proses dari pengolahan data transaksi penjualan produk kartu perdana kuota internet serta kebutuhan data pendukung lainnya, terakhir melakukan studi literatur untuk mendapatkan teori - teori pendukung yang berhubungan dengan konsep dari penerapan Algoritma Apriori.

\subsection{Identifikasi Penerapan Association Rule Mining Algoritma Apriori}

Analisa asosiatif yang digunakan pada penelitian ini yaitu untuk mencari kombinasi itemset pada data transaksi penjualan produk kartu perdana kuota internet yang menjadi objek penentuan aturan asosiasi untuk menemukan aturan dasar kombinasi item- item produk operator mana saja yang paling laku terjual dan menghitung banyaknya transaksi yang terjadi dalam setiap kombinasi tersebut.

Proses perhitungan aturan asosiasi dikelompokkan sesuai dengan masing-masing wilayah penjualannya. Hasil aturan asosiasi dari setiap wilayah dapat dibandingkan untuk melihat kombinasi itemitem mana saja yang memiliki penjualan produk kartu perdana kuota internet yang terbaik, sehingga dapat dijadikan sebagai bahan acuan untuk melakukan strategi pemasaran produk sesuai dengan target penjualan yang dicapai. Adapun metodologi dasar analisis asosiasi terbagi menjadi dua tahap, yaitu [6]:

a) Analisa Pola Frekuensi Tinggi

Pada tahap ini dicari kombinasi item yang memenuhi syarat minimum dari nilai support dalam database. Nilai support sebuah item diperoleh dengan rumus berikut:

Support $(A)=\frac{\text { Jumlah transaksi untuk } A}{\text { Total Transaksi }}$

Rumus support tersebut menjelaskan bahwa nilai support didapat dengan cara membagi jumlah transaksi yang mengandung item A (satu item) dengan jumlah total seluruh transaksi. Sedangkan untuk mencari nilai support dari 2-itemset dan seterusnya menggunakan rumus berikut:

$$
\begin{aligned}
& \text { Support }(A, B)=\frac{\sum \text { Transaksi untuk } A \text { dan } B}{\text { Total Transaksi }} \\
& \text { Support }(A, B, C)=\frac{\sum \text { transaksi untuk } A, B \text { dan } C}{\text { Total Transaksi }}
\end{aligned}
$$

b) Pembentukan Aturan Asosiasi

Setelah semua pola frekuensi tinggi ditemukan, berikutnya mencari aturan asosiasi yang memenuhi syarat minimum untuk mengetahui confidence dengan menghitung nilai confidence aturan assosiatif $\mathrm{A} \rightarrow \mathrm{B}$. Nilai confidence dari aturan $\mathrm{A} \rightarrow \mathrm{B}$ diperoleh dari rumus sebagai berikut:

$$
\text { Confidence }(A \rightarrow B)=\frac{\Sigma \text { transaksi untuk } A \text { dan } B}{\Sigma \text { Transaksi } A}
$$

Rumus diatas menjelaskan bahwa nilai dari confidence diperoleh dengan menggunakan cara melakukan pembagian dari jumlah transaksi yang mengandung item A dan item B (item pertama bersamaan dengan item yang lain) dengan jumlah transaksi yang mengandung item A (item pertama atau item yang ada disebelah kiri).

Algoritma apriori meruapakan salah satu algoritma yang digunakan untuk melakukan proses pencarian frequent itemset dengan association rules. Algoritma apriori menggunakan pendekatan level wise search, dimana k-itemset digunakan untuk memperoleh $(\mathrm{k}+1)$ itemset. Proses ini dilakukan hingga tidak ada lagi kombinasi yang dapat dibentuk [7]. Pembentukan pola asosiasi oleh algoritma apriori terdiri dari dua tahap yaitu tahap pertama mencari frequent itemset (himpunan item yang memenuhi nilai minimum support), selanjutnya tahap kedua membentuk pola asosiasi dari frequent itemset yang telah didapat dengan menggunakan nilai confidence [2].

\subsection{Pengembangan Sistem}

Pengembangan sistem merupakan tahapan dalam membangun sebuah perangkat lunak untuk kebutuhan data informasi dalam melakukan proses pengolahan data. Sistem yang dibangun adalah sistem yang mengimplementasikan metode association rule mining menggunakan perhitungan algoritma apriori untuk menemukan kombinasi item produk operator kartu kuota internet mana saja yang paling laku terjual 
sebagai data analisa untuk mengetahui tingkat pemasaran dan penjualan produk yang sudah dicapai. Model proses untuk pengembangan perangkat lunak menggunakan model Extreme Programming (XP), dimana model tersebut model yang paling banyak digunakan untuk pengembangan perangkat lunak cepat. Model tersebut memiliki tahapan-tahapan yang terdiri dari : Planning (Perencanaan), Design (Perancangan), Coding (Pengkodean), dan Testing [8].

\subsection{Pengujian}

Pada tahap penelitian ini dilakukan untuk menguji penerapan dari metode association rule mining pada aplikasi yang telah diimplementasikan menggunakan perhitungan algoritma apriori. Pengujian ini bertujuan untuk membandingkan perhitungan yang dilakukan antara perhitungan manual dengan perhitungan sistem yang telah dibangun, hal ini berguna untuk mengetahui bahwa perhitungan yang dilakukan oleh sistem sudah sesuai dengan konsep perhitungan algoritma apriori itu sendiri.

\section{HASIL DAN PEMBAHASAN}

\subsection{Analisa Aturan Asosiasi Perhitungan Algoritma Apriori}

Sumber data yang diambil pada penelitian ini adalah data dari Divisi Broadband and Digital Sales PT. Telkomsel Branch Tasikmalaya yang memiliki tugas utama untuk melakukan pendataan ke setiap pasar outlet dalam memantau pencapaian penjualan serta pembelian berupa produk kartu perdana kuota internet, kartu perdana segel, omset m-kios serta penjualan device handphone dan lainnya untuk mengetahui market share tingkat pangsa pasar penjualan berbagai produk yang telah didistribusikan oleh operator telekomunikasi seluler lainnya.

Data yang dianalisa adalah data transaksi penjualan produk kartu perdana kuota internet. Total sampel data yang diambil adalah 614 data transaksi dari jumlah data transaksi keseluruhan dari bulan Maret sampai bulan Juli 2018, kemudian dibagi menjadi tiga berdasarkan wilayah penjualan di Priangan Timur, meliputi cluster Ciamis memiliki 208 data transaksi, cluster Tasikmalaya memliki 205 data transaksi dan cluster Garut memiliki 201 data transaksi. Terdapat 6 item atau atribut data yang digunakan dalam melakukan aturan asosiasi dengan nilai minimum support yang ditentukan yaitu $35 \%$ dan nilai minimum confidence yaitu $80 \%$. Berikut adalah tabel 1 dari jumlah data transaksi proses mining aturan asosiasi dalam perhitungan algoritma apriori.

Tabel 1. Jumlah data transakasi

\begin{tabular}{ccccc}
\hline No & Cluster & Jumlah Data Transaksi & Min_Support & Min_Confidence \\
\hline 1 & Ciamis & 208 & $35 \%$ & $80 \%$ \\
2 & Tasikmalaya & 205 & $35 \%$ & $80 \%$ \\
3 & Garut & 201 & $35 \%$ & $80 \%$ \\
\hline
\end{tabular}

\subsection{Proses Perhitungan Algoritma Apriori}

Pada Tabel 2. Diketahui contoh sampel data transaksi penjualan produk kartu perdana kuota internet yang telah dilakukan pendataan ke setiap pasar outlet yang ada diwilayah penjualan Priangan Timur meliputi cluster Ciamis, Tasikmalaya dan Garut.

Tabel 2. Sampel data transakasi penjualan produk kartu perdana kuota internet

\begin{tabular}{cccccccccc}
\hline No & Tanggal & Nama Outlet & Cluster & Tsel & XL & Isat & Tree & Axis & Smartfren \\
\hline 1 & $23-03-2018$ & Agro Cell & Ciamis & 150 & 125 & 130 & 95 & 80 & 45 \\
2 & $23-03-2018$ & Budi Cell & Ciamis & 185 & 0 & 0 & 0 & 0 & 0 \\
3 & $23-03-2018$ & Phoenix Cell & Tasikmalaya & 125 & 85 & 75 & 65 & 90 & 45 \\
4 & $23-03-2018$ & Hoky Cell & Tasikmalaya & 140 & 0 & 0 & 70 & 100 & 39 \\
5 & $23-03-2018$ & Agro Cell & Ciamis & 146 & 0 & 100 & 92 & 125 & 0 \\
6 & $23-03-2018$ & Budi Cell & Garut & 125 & 0 & 95 & 90 & 110 & 40 \\
7 & $23-03-2018$ & WM Cell & Garut & 80 & 0 & 87 & 50 & 86 & 16 \\
8 & $23-03-2018$ & Yoma Cell & Tasikmalaya & 135 & 120 & 100 & 90 & 95 & 45 \\
$\ldots$ & $\ldots$ & $\ldots$ & $\ldots$ & $\ldots$ & $\ldots$ & $\ldots$ & $\ldots$ & $\ldots$ & $\ldots$ \\
614 & $30-07-2018$ & Nanda Cell & Tasikmalaya & 125 & 88 & 95 & 45 & 75 & 35 \\
\hline
\end{tabular}

Data transaksi tersebut dijabarkan dalam bentuk tabular menjadi 1-itemset, fungsinya nanti adalah untuk mendapatkan calon $(\mathrm{k}+1)$-itemset berikutnya. 


\subsubsection{Pembentukan Kandidat 1-Itemset}

Proses pembentukan kandidat 1-Itemset pada masing - masing setiap wilayah dengan jumlah minimum support yang ditentukan sebesar 35\% kemudian hitung jumlah kemunculannya pada setiap transaksi yang tercantum pada tabel 3, tabel 4 dan tabel 5 dibawah ini.

Tabel 3. Kandidat 1-itemset cluster ciamis

\begin{tabular}{cccc}
\hline No & Nama Itemset & Jumlah Item $(\boldsymbol{X})$ & Support $(\boldsymbol{X})$ \\
\hline 1 & Telkomsel & 152 & $(152 / 208) \times 100 \%=73,08 \%$ \\
2 & XL & 114 & $(114 / 208) \times 100 \%=54,81 \%$ \\
3 & Indosat & 113 & $(113 / 208) \times 100 \%=54,33 \%$ \\
4 & Tree & 96 & $(96 / 208) \times 100 \%=46,15 \%$ \\
5 & Axis & 105 & $(105 / 208) \times 100 \%=50,48 \%$ \\
6 & Smartfren & 91 & $(91 / 208) \times 100 \%=43,75 \%$ \\
\hline
\end{tabular}

Tabel 4. Kandidat 1-itemset cluster Tasikmalaya

\begin{tabular}{cccc}
\hline No & Nama Itemset & Jumlah Item $(\boldsymbol{X})$ & Support $(\boldsymbol{X})$ \\
\hline 1 & Telkomsel & 146 & $(146 / 205) \times 100 \%=71,22 \%$ \\
2 & XL & 98 & $(98 / 205) \times 100 \%=47,80 \%$ \\
3 & Indosat & 129 & $(129 / 205) \times 100 \%=62,93 \%$ \\
4 & Tree & 112 & $(112 / 205) \times 100 \%=54,63 \%$ \\
5 & Axis & 116 & $(116 / 205) \times 100 \%=56,59 \%$ \\
6 & Smartfren & 91 & $(91 / 205) \times 100 \%=44,39 \%$ \\
\hline
\end{tabular}

Tabel 5. Kandidat 1-itemset cluster Garut

\begin{tabular}{cccc}
\hline No & Nama Itemset & Jumlah Item $(\boldsymbol{X})$ & Support $(\boldsymbol{X})$ \\
\hline 1 & Telkomsel & 149 & $(149 / 201) \times 100 \%=74,13 \%$ \\
2 & XL & 109 & $(109 / 201) \times 100 \%=54,23 \%$ \\
3 & Indosat & 108 & $(109 / 201) \times 100 \%=53,73 \%$ \\
4 & Tree & 95 & $(95 / 201) \times 100 \%=47,26 \%$ \\
5 & Axis & 110 & $(110 / 201) \times 100 \%=54,73 \%$ \\
6 & Smartfren & 86 & $(86 / 201) \times 100 \%=42,79 \%$ \\
\hline
\end{tabular}

Dapat diketahui total untuk setiap item yang didapat pada kandidat 1-itemset, jika dilihat dari tabel 3, 4 dan 5 diatas semua jumlah item frekuensi itemset-nya lebih besar dari nilai minimum support yang ditelah ditentukan yaitu $35 \%$.

\subsubsection{Pembentukan Kandidat 2-Itemset}

Pembentukan kandidat 2-itemset atau kombinasi dari 2-itemset data untuk semua item sehingga tidak bisa lagi dikombinasikan (disebut calon kombinasi 2-itemset atau calon F2) dengan memasangkan satu item dengan item lainnya. Kombinasi yang telah dibentuk kemudian hitung jumlah kemunculannya pada setiap transaksi. Selanjutnya pemangkasan atau pembuangan itemset yang memiliki nilai kurang dari minimum support 35\% yang telah ditentukan. Hal ini dilakukan untuk menemukan F2 akhir. Proses pembentukan kandidat 2-itemset dapat dilihat pada tabel 6, tabel 7 dan tabel 8.

Tabel 6. Kandidat 2-itemset cluster Ciamis

\begin{tabular}{clcc}
\hline No & \multicolumn{1}{c}{ Nama Itemset } & Jumlah Item $(\boldsymbol{X n Y})$ & \multicolumn{1}{c}{ Support $(\boldsymbol{X n Y})$} \\
\hline 1 & Telkomsel, XL & 109 & $(109 / 208) \times 100 \%=52,40 \%$ \\
2 & Telkomsel, Indosat & 105 & $(105 / 208) \times 100 \%=50,48 \%$ \\
3 & Telkomsel, Tree & 91 & $(91 / 208) \times 100 \%=43,75 \%$ \\
4 & Telkomsel, Axis & 96 & $(96 / 208) \times 100 \%=46,15 \%$ \\
5 & Telkomsel, Smartfren & 86 & $(86 / 208) \times 100 \%=41,35 \%$ \\
6 & XL, Indosat & 79 & $(79 / 208) \times 100 \%=37,98 \%$ \\
7 & XL, Tree & 74 & $(74 / 208) \times 100 \%=35,58 \%$ \\
8 & XL, Axis & 75 & $(75 / 208) \times 100 \%=36,06 \%$ \\
9 & XL, Smartfren & 73 & $(73 / 208) \times 100 \%=35,10 \%$ \\
10 & Indosat, Axis & 77 & $(77 / 208) \times 100 \%=37,02 \%$ \\
\hline
\end{tabular}


Tabel 7. Kandidat 2-itemset cluster Tasikmalaya

\begin{tabular}{clcl}
\hline No & \multicolumn{1}{c}{ Nama Itemset } & Jumlah Item $(\boldsymbol{X n Y})$ & \multicolumn{1}{c}{ Support $(\boldsymbol{X n Y})$} \\
\hline 1 & Telkomsel, XL & 91 & $(91 / 205) \times 100 \%=44,39 \%$ \\
2 & Telkomsel, Indosat & 119 & $(119 / 205) \times 100 \%=58,05 \%$ \\
3 & Telkomsel, Tree & 104 & $(104 / 205) \times 100 \%=50,73 \%$ \\
4 & Telkomsel, Axis & 106 & $(106 / 205) \times 100 \%=51,71 \%$ \\
5 & Telkomsel, Smartfren & 82 & $(82 / 205) \times 100 \%=40,00 \%$ \\
6 & XL, Indosat & 84 & $(84 / 205) \times 100 \%=40,98 \%$ \\
7 & XL, Tree & 75 & $(75 / 205) \times 100 \%=36,59 \%$ \\
8 & XL, Axis & 76 & $(76 / 205) \times 100 \%=37,07 \%$ \\
9 & Indosat, Tree & 97 & $(97 / 205) \times 100 \%=47,32 \%$ \\
10 & Indosat, Axis & 101 & $(101 / 205) \times 100 \%=49,27 \%$ \\
11 & Indosat, Smartfren & 77 & $(77 / 205) \times 100 \%=37,56 \%$ \\
12 & Tree, Axis & 85 & $(85 / 205) \times 100 \%=41,46 \%$ \\
13 & Tree, Smartfren & 75 & $(75 / 205) \times 100 \%=36,59 \%$ \\
\hline
\end{tabular}

Tabel 8. Kandidat 2-itemset cluster Garut

\begin{tabular}{clcl}
\hline No & \multicolumn{1}{c}{ Nama Itemset } & Jumlah Item $(\boldsymbol{X n Y})$ & \multicolumn{1}{c}{ Support $(\boldsymbol{X n Y})$} \\
\hline 1 & Telkomsel, XL & 106 & $(106 / 201) \times 100 \%=52,74 \%$ \\
2 & Telkomsel, Indosat & 101 & $(101 / 201) \times 100 \%=50,25 \%$ \\
3 & Telkomsel, Tree & 88 & $(88 / 201) \times 100 \%=43,78 \%$ \\
4 & Telkomsel, Axis & 103 & $(103 / 201) \times 100 \%=51,24 \%$ \\
5 & Telkomsel, Smartfren & 79 & $(79 / 201) \times 100 \%=39,30 \%$ \\
6 & XL, Indosat & 75 & $(75 / 201) \times 100 \%=37,31 \%$ \\
7 & XL, Axis & 79 & $(79 / 201) \times 100 \%=39,30 \%$ \\
8 & Indosat, Axis & 77 & $(77 / 201) \times 100 \%=38,31 \%$ \\
\hline
\end{tabular}

\subsubsection{Pembentukan Kandidat 3-Itemset}

Setelah menemukan Frekuensi 2-itemset akhir, kemudian melanjutkan untuk menemukan kembali kombinasi 3-itemset. Buat kombinasi 3-itemset untuk semua item sehingga tidak bisa lagi dikombinasikan dengan cara yang sama yaitu memasangkan item satu dengan item lain sehingga membentuk calon kandidat 3-itemset. Selanjutnya pemangkasan atau pembuangan itemset yang memiliki nilai kurang dari minimum support $35 \%$ yang telah ditentukan. Hal ini dilakukan untuk menemukan F3 akhir. Proses tersebut dapat dilihat pada tabel 9, tabel 10 dan tabel 11.

Tabel 9. Kandidat 3-itemset cluster Ciamis

\begin{tabular}{cccc}
\hline No & Nama Itemset & Jumlah Item $($ XnYnZ) & Support $($ XnYnZ) \\
\hline 1 & Telkomsel, XL, Indosat & 75 & $(75 / 208) \times 100 \%=36,06 \%$ \\
2 & Telkomsel, XL, Tree & 73 & $(73 / 208) \times 100 \%=35,10 \%$ \\
\hline
\end{tabular}

Tabel 10. Kandidat 3-itemset cluster Tasikmalaya

\begin{tabular}{clcc}
\hline No & \multicolumn{1}{c}{ Nama Itemset } & Jumlah Item $(\boldsymbol{X n Y n Z})$ & Support $(\boldsymbol{X n Y n Z})$ \\
\hline 1 & Telkomsel, XL, Indosat & 79 & $(79 / 205) \times 100 \%=38,54 \%$ \\
2 & Telkomsel, XL, Tree & 72 & $(72 / 205) \times 100 \%=35,12 \%$ \\
3 & Telkomsel, Indosat, Tree & 91 & $(91 / 205) \times 100 \%=44,39 \%$ \\
4 & Telkomsel, Indosat, Axis & 92 & $(92 / 205) \times 100 \%=44,88 \%$ \\
5 & Telkomsel, Tree, Axis & 79 & $(79 / 205) \times 100 \%=38,54 \%$ \\
6 & Indosat, Tree, Axis & 78 & $(78 / 205) \times 100 \%=38,05 \%$ \\
\hline
\end{tabular}

Tabel 11. Kandidat 3-Itemset Cluster Garut

\begin{tabular}{cccc}
\hline No & Nama Itemset & Jumlah Item $($ XnYnZ) & Support $($ XnYnZ) \\
\hline 1 & Telkomsel, XL, Indosat & 73 & $(73 / 201) \times 100 \%=36,32 \%$ \\
2 & Telkomsel, XL, Axis & 77 & $(77 / 201) \times 100 \%=38,31 \%$ \\
\hline
\end{tabular}

\subsubsection{Nilai Confidence dari Frekuensi 2-Itemset (F2) dan Frekuensi 3-Itemset (F3)}

Sebelum menghitung nilai confidence dilakukan terlebih dahulu pertukaran itemset. Misal suatu kombinasi pada itemset 2 yaitu $\mathrm{A} \rightarrow \mathrm{B}$, maka dibalik menjadi $\mathrm{B} \rightarrow \mathrm{A}$. contoh lainnya adalah suatu kombinasi pada itemset 3 , yaitu $\mathrm{A}, \mathrm{B} \rightarrow \mathrm{C}$, itemset tersebut bisa dibalik menjadi $\mathrm{A}, \mathrm{C} \rightarrow \mathrm{B}$ dan $\mathrm{B}, \mathrm{C} \rightarrow \mathrm{A}$. 
Nilai support pada masing masing itemset tersebut tetap sama, akan tetapi kemungkinan nilai confidence bisa berbeda. Hal tersebut juga agar dapat diketahui mana nilai confidence yang terbesar dari tiap itemset tersebut [9]. Selanjutnya pemangkasan atau pembuangan itemset yang memiliki nilai kurang dari minimum confidence $80 \%$ yang telah ditentukan. Tabel 12, 13,14,15,16,17 dibawah ini merupakan aturan asosiasi frekuensi 2-Itemset yang memenuhi syarat minimum confidence yang telah ditentukan.

Tabel 12. Calon aturan asosiasi frekuensi 2-itemset cluster Ciamis

\begin{tabular}{clcccc}
\hline No & Calon Aturan Asosiasi & Jumlah Item $(\boldsymbol{X n Y})$ & Jumlah Item(X) & Support (\%) & Confidence (\%) \\
\hline 1 & XL $\rightarrow$ Telkomsel & 109 & 114 & $52,40 \%$ & $95,61 \%$ \\
2 & Indosat $\rightarrow$ Telkomsel & 105 & 113 & $50,48 \%$ & $92,92 \%$ \\
3 & Tree $\rightarrow$ Telkomsel & 91 & 96 & $43,75 \%$ & $94,79 \%$ \\
4 & Axis $\rightarrow$ Telkomsel & 96 & 105 & $46,15 \%$ & $91,43 \%$ \\
5 & Smartfren $\rightarrow$ Telkomsel & 86 & 91 & $41,35 \%$ & $94,51 \%$ \\
6 & Smartfren $\rightarrow$ XL & 73 & 91 & $35,10 \%$ & $80,22 \%$ \\
\hline
\end{tabular}

Tabel 13. Calon aturan asosiasi frekuensi 3-itemset cluster Ciamis

\begin{tabular}{clcccc}
\hline \multirow{2}{*}{ No } & \multicolumn{1}{c}{ Calon Aturan Asosiasi } & $\begin{array}{c}\text { Jumlah } \\
\text { Item(XnYnZ) }\end{array}$ & $\begin{array}{c}\text { Jumlah } \\
\text { Item(XnY) }\end{array}$ & $\begin{array}{c}\text { Support } \\
(\%)\end{array}$ & $\begin{array}{c}\text { Confidence } \\
(\%)\end{array}$ \\
\hline 1 & XL, Indosat $\rightarrow$ Telkomsel & 75 & 79 & $36,06 \%$ & $94,94 \%$ \\
2 & Telkomsel, Tree $\rightarrow$ XL & 73 & 91 & $35,10 \%$ & $80,22 \%$ \\
3 & XL, Tree $\rightarrow$ Telkomsel & 73 & 74 & $35,10 \%$ & $98,65 \%$ \\
\hline
\end{tabular}

Tabel 14. Calon aturan asosiasi frekuensi 2-itemset cluster Tasikmalaya

\begin{tabular}{clcccc}
\hline No & Calon Aturan Asosiasi & Jumlah Item(XnY) & Jumlah Item(X) & Support (\%) & Confidence (\%) \\
\hline 1 & XL $\rightarrow$ Telkomsel & 91 & 98 & $44,39 \%$ & $92,86 \%$ \\
2 & Telkomsel $\rightarrow$ Indosat & 119 & 146 & $58,05 \%$ & $81,51 \%$ \\
3 & Indosat $\rightarrow$ Telkomsel & 119 & 129 & $58,05 \%$ & $92,25 \%$ \\
4 & Tree $\rightarrow$ Telkomsel & 104 & 112 & $50,73 \%$ & $92,86 \%$ \\
5 & Axis $\rightarrow$ Telkomsel & 106 & 116 & $51,71 \%$ & $91,38 \%$ \\
6 & Smartfren $\rightarrow$ Telkomsel & 82 & 91 & $40,00 \%$ & $90,11 \%$ \\
7 & XL $\rightarrow$ Indosat & 84 & 98 & $40,98 \%$ & $85,71 \%$ \\
8 & Tree $\rightarrow$ Indosat & 97 & 112 & $47,32 \%$ & $86,61 \%$ \\
9 & Axis $\rightarrow$ Indosat & 101 & 116 & $49,27 \%$ & $87,07 \%$ \\
10 & Smartfren $\rightarrow$ Indosat & 77 & 91 & $37,56 \%$ & $84,62 \%$ \\
11 & Smartfren $\rightarrow$ Tree & 75 & 91 & $36,59 \%$ & $82,42 \%$ \\
\hline
\end{tabular}

Tabel 15. Calon aturan asosiasi frekuensi 3-itemset cluster Tasikmalaya

\begin{tabular}{clcccc}
\hline No & \multicolumn{1}{c}{ Calon Aturan Asosiasi } & $\begin{array}{c}\text { Jumlah } \\
\text { Item }(\text { XnYnZ) }\end{array}$ & $\begin{array}{c}\text { Jumlah } \\
\text { Item }(\boldsymbol{X n Y})\end{array}$ & $\begin{array}{c}\text { Support } \\
(\%)\end{array}$ & $\begin{array}{c}\text { Confidence } \\
(\%)\end{array}$ \\
\hline 1 & Telkomsel, XL $\rightarrow$ Indosat & 79 & 91 & $38,54 \%$ & $86,81 \%$ \\
2 & XL, Indosat $\rightarrow$ Telkomsel & 79 & 84 & $38,54 \%$ & $94,05 \%$ \\
3 & XL, Tree $\rightarrow$ Telkomsel & 72 & 75 & $35,12 \%$ & $96,00 \%$ \\
4 & Telkomsel, Tree $\rightarrow$ Indosat & 91 & 104 & $44,39 \%$ & $87,50 \%$ \\
5 & Indosat, Tree $\rightarrow$ Telkomsel & 91 & 97 & $44,39 \%$ & $93,81 \%$ \\
6 & Telkomsel, Axis $\rightarrow$ Indosat & 92 & 106 & $44,88 \%$ & $86,79 \%$ \\
7 & Indosat, Axis $\rightarrow$ Telkomsel & 92 & 101 & $44,88 \%$ & $91,09 \%$ \\
8 & Tree, Axis $\rightarrow$ Telkomsel & 79 & 85 & $38,54 \%$ & $92,94 \%$ \\
9 & Indosat, Tree $\rightarrow$ Axis & 78 & 97 & $38,05 \%$ & $80,41 \%$ \\
10 & Tree, Axis $\rightarrow$ Indosat & 78 & 85 & $38,05 \%$ & $91,76 \%$ \\
\hline
\end{tabular}

Tabel 16. Calon aturan asosiasi frekuensi 2-itemset cluster Garut

\begin{tabular}{clcccc}
\hline No & Calon Aturan Asosiasi & Jumlah Item(XnY) & Jumlah Item(X) & Support (\%) & Confidence (\%) \\
\hline 1 & XL $\rightarrow$ Telkomsel & 106 & 109 & $52,74 \%$ & $97,25 \%$ \\
2 & Indosat $\rightarrow$ Telkomsel & 101 & 108 & $50,25 \%$ & $93,52 \%$ \\
3 & Tree $\rightarrow$ Telkomsel & 88 & 95 & $43,78 \%$ & $92,63 \%$ \\
4 & Axis $\rightarrow$ Telkomsel & 103 & 110 & $51,24 \%$ & $93,64 \%$ \\
5 & Smartfren $\rightarrow$ Telkomsel & 79 & 86 & $39,30 \%$ & $91,86 \%$ \\
\hline
\end{tabular}


Tabel 17. Calon aturan asosiasi frekuensi 3-itemset cluster Garut

\begin{tabular}{cccccc}
\hline No & Calon Aturan Asosiasi & $\begin{array}{c}\text { Jumlah } \\
\text { Item(XnYnZ) }\end{array}$ & $\begin{array}{c}\text { Jumlah } \\
\text { Item(XnY) }\end{array}$ & $\begin{array}{c}\text { Support } \\
(\%)\end{array}$ & $\begin{array}{c}\text { Confidence } \\
(\%)\end{array}$ \\
\hline 1 & XL, Indosat $\rightarrow$ Telkomsel & 73 & 75 & $36,32 \%$ & $97,33 \%$ \\
2 & XL, Axis $\rightarrow$ Telkomsel & 77 & 79 & $38,31 \%$ & $97,47 \%$ \\
\hline
\end{tabular}

\subsubsection{Pembentukan Aturan Asosiasi Final}

Setelah didapat nilai Support dan Confidence untuk masing-masing kandidat lakukan perkalian antara Support dan Confidence. Setelah didapat hasil perkalian antara nilai Support dan Confidence pilihlah yang hasil perkaliannya paling besar. Hasil paling besar dari perkalian - perkalian tersebut merupakan rule yang di pakai dalam aturan Asosiasi final. Tabel 18, 19, 20 di bawah ini merupakan aturan asosiasi final pada setiap wilayah.

Tabel 18. Aturan asosiasi final cluster Ciamis

\begin{tabular}{clccc}
\hline No & If Antecedent, then Consequent & Support (\%) & Confidence (\%) & Support C Confidence \\
\hline 1 & If XL and Indosat, Then Telkomsel & $36,06 \%$ & $94,94 \%$ & 0,3424 \\
2 & If Telkomsel and Tree, Then XL & $35,10 \%$ & $80,22 \%$ & 0,2816 \\
3 & If XL and Tree, Then Telkomsel & $35,10 \%$ & $98,65 \%$ & 0,3463 \\
4 & If XL, Then Telkomsel & $52,40 \%$ & $95,61 \%$ & 0,5010 \\
5 & If Indosat, Then Telkomsel & $50,48 \%$ & $92,92 \%$ & 0,4691 \\
6 & If Tree, Then Telkomsel & $43,75 \%$ & $94,79 \%$ & 0,4147 \\
7 & If Axis, Then Telkomsel & $46,15 \%$ & $94,43 \%$ & 0,4358 \\
8 & If Smartfren, Then Telkomsel & $41,35 \%$ & $94,51 \%$ & 0,3908 \\
9 & If Smartfren, Then XL & $35,10 \%$ & $80,22 \%$ & 0,2816 \\
\hline
\end{tabular}

Tabel 19. Aturan asosiasi final cluster Tasikmalaya

\begin{tabular}{ccccc}
\hline No If Antecedent, then Consequent & Support (\%) & Confidence (\%) & Support $\boldsymbol{x}$ Confidence \\
\hline 1 & If Telkomsel and XL, Then Indosat & $38,54 \%$ & $86,81 \%$ & 0,3346 \\
2 & If XL and Indosat, Then Telkomsel & $38,54 \%$ & $94,05 \%$ & 0,3625 \\
3 & If XL and Tree, Then Telkomsel & $35,12 \%$ & $96,00 \%$ & 0,3372 \\
4 & If Telkomsel and Tree, Then Indosat & $44,39 \%$ & $87,50 \%$ & 0,3884 \\
5 & If Indosat and Tree, Then Telkomsel & $44,39 \%$ & $93,81 \%$ & 0,4164 \\
6 & If Telkomsel and Axis, Then Indosat & $44,88 \%$ & $86,79 \%$ & 0,3895 \\
7 & If Indosat and Axis, Then Telkomsel & $44,88 \%$ & $91,09 \%$ & 0,4088 \\
8 & If Tree and Axis, Then Telkomsel & $38,54 \%$ & $92,94 \%$ & 0,3582 \\
9 & If Indosat and Tree, Then Axis & $38,05 \%$ & $80,41 \%$ & 0,3060 \\
10 & If Tree and Axis, Then Indosat & $38,05 \%$ & $91,76 \%$ & 0,3491 \\
11 & If XL, Then Telkomsel & $44,39 \%$ & $92,86 \%$ & 0,4122 \\
12 & If Telkomsel, Then Indosat & $58,05 \%$ & $81,51 \%$ & 0,4732 \\
13 & If Indosat, Then Telkomsel & $58,05 \%$ & $92,25 \%$ & 0,5355 \\
14 & If Tree, Then Telkomsel & $50,73 \%$ & $92,86 \%$ & 0,4711 \\
15 & If Axis, Then Telkomsel & $51,71 \%$ & $91,38 \%$ & 0,4725 \\
16 & If Smartfren, Then Telkomsel & $40,00 \%$ & $90,11 \%$ & 0,3604 \\
17 & If XL, Then Indosat & $40,98 \%$ & $85,71 \%$ & 0,3512 \\
18 & If Tree, Then Indosat & $47,32 \%$ & $86,61 \%$ & 0,4098 \\
19 & If Axis, Then Indosat & $49,27 \%$ & $87,07 \%$ & 0,4290 \\
20 & If Smartfren, Then Indosat & $37,56 \%$ & $84,62 \%$ & 0,3178 \\
21 & If Smartfren, Then Tree & $36,59 \%$ & $82,42 \%$ & 0,3016 \\
\hline
\end{tabular}

Tabel 20. Aturan asosiasi final cluster Garut

\begin{tabular}{clccc}
\hline No & If Antecedent, then Consequent & Support (\%) & Confidence (\%) & Support $\boldsymbol{x}$ Confidence \\
\hline 1 & If XL and Indosat, Then Telkomsel & $36,32 \%$ & $97,33 \%$ & 0,3535 \\
2 & If XL and Axis, Then Telkomsel & $38,31 \%$ & $97,47 \%$ & 0,3734 \\
3 & If XL, Then Telkomsel & $52,74 \%$ & $97,25 \%$ & 0,5129 \\
4 & If Indosat, Then Telkomsel & $50,25 \%$ & $93,52 \%$ & 0,4699 \\
5 & If Tree, Then Telkomsel & $43,78 \%$ & $92,63 \%$ & 0,4055 \\
6 & If Axis, Then Telkomsel & $51,24 \%$ & $93,64 \%$ & 0,4798 \\
7 & If Smartfren, Then Telkomsel & $39,30 \%$ & $91,86 \%$ & 0,3610 \\
\hline
\end{tabular}


Berdasarkan hasil informasi yang telah disampaikan, terdapat dua tolak ukur penilaian yaitu Support dan Confidence. Nilai Support dapat digunakan untuk mengukur kemungkinan sebuah itemset diambil atau digunakan secara bersamaan, sedangkan Nilai Confidence digunakan untuk mengukur kepastian hubungan antar itemset [10]. Tahap ini merupakan kesimpulan akhir dari proses apriori yang nantinya menjelaskan bahwa aturan asosiasi yang mempunyai pengaruh paling kuat adalah aturan yang memiliki nilai perkalian support dan confidence yang paling tinggi [11].

\subsection{Identifikasi Masalah}

Tahap ini dilakukan proses identifikasi permasalahan untuk mengetahui proses yang sedang berjalan di Divisi Broadband and Digital Sales PT. Telkomsel Branch Tasikmalaya dimana sistem yang berjalan saat ini dilakukan yaitu:

a) Proses pendataan yang dilakukan masih memanfaatkan google document dan belum adanya sistem yang dapat terintegrasi langsung pada database penyimpanan khusus dalam melakukan transaksi pencapaian penjualan.

b) Tidak adanya proses analisa yang dilakukan terhadap data yang telah didapat dan data tersebut hanya dijadikan sebagai arsip penyimpanan perusahaan, sehingga minimnya informasi dalam melakukan analisa terhadap penyusunan strategi pemasaran produk.

\subsection{Analisa Sistem Baru}

Sistem yang dibangun ini diberi nama Sistem Informasi Ritel Outlet (S.I.R.O) merupakan sistem berbasis android dan web. Proses yang dilakukan oleh sistem tersebut dalam penerapan metode association rule mining algoritma apriori adalah sebagai berikut:

a) Sistem ini dapat menganalisa database transaksi penjualan berupa produk kartu perdana kuota internet dengan menggunakan Algoritma Apriori yang diimplementasikan pada aplikasi web.

b) Sistem ini menghasilkan output dari item-item yang saling berasosiasi dengan menghitung besarnya nilai support dan confidence berdasarkan nilai minimum yang telah ditentukan.

c) Sistem ini dapat memberikan informasi hasil analisa kombinasi item-item atau produk kartu kuota internet mana saja yang sering dibeli atau dijual oleh pasar outlet seluler, sehingga dapat mengetahui hasil analisa penjualan produk operator mana saja yang paling laku terjual secara bersamaan dengan operator telekomunikasi seluler lainnya.

\subsection{Perancangan Arsitektur Sistem}

Perancangan arsitektur sistem yang dibangun pada penelitian ini menggunakan teknologi berbasis client-server, dimana aplikasi yang dibangun ini merupakan sistem dengan berbasis aplikasi android yang dapat digunakan oleh sales agent dan aplikasi web dapat digunakan oleh admin dan supervisor yang harus terkoneksi dengan internet sehingga dapat terintegrasi langsung kedalam server database. Rancangan arsitektur sistem informasi ritel outlet tercantum pada gambar 1.

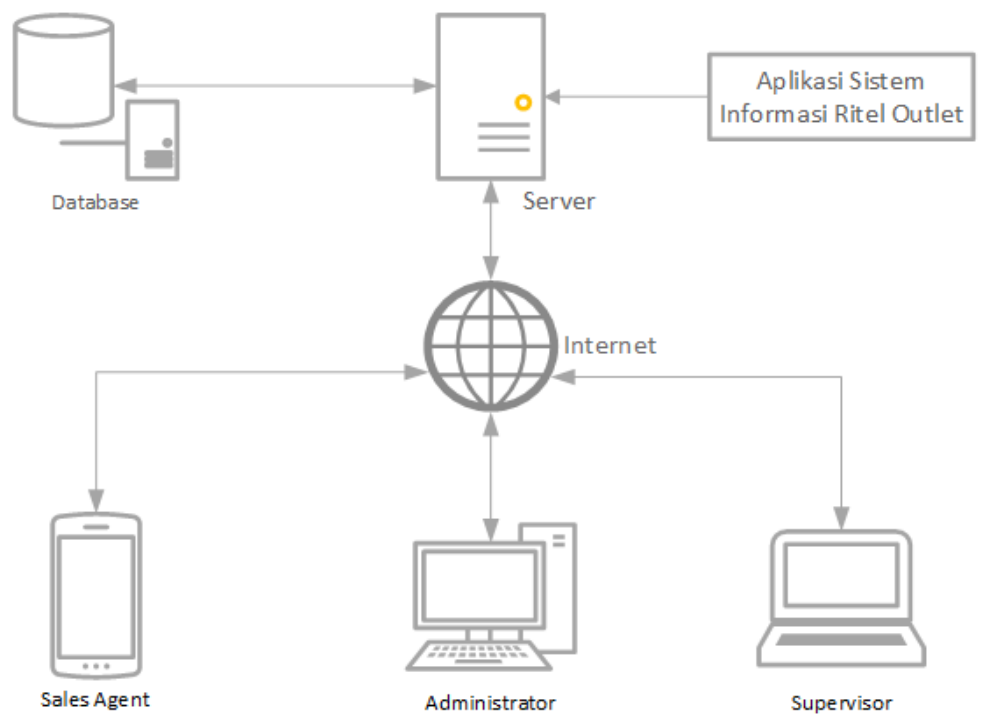

Gambar 1. Perancangan Arsitektur Sistem Informasi Ritel Outlet 


\subsection{Aliran Sistem Penerapan Algoritma Apriori}

Aliran sistem flowchart ini menggambarkan alur proses penerapan metode association rule mining menggunakan perhitungan algoritma apriori pada sistem yang dikembangkan, dapat dilihat pada gambar 2 .

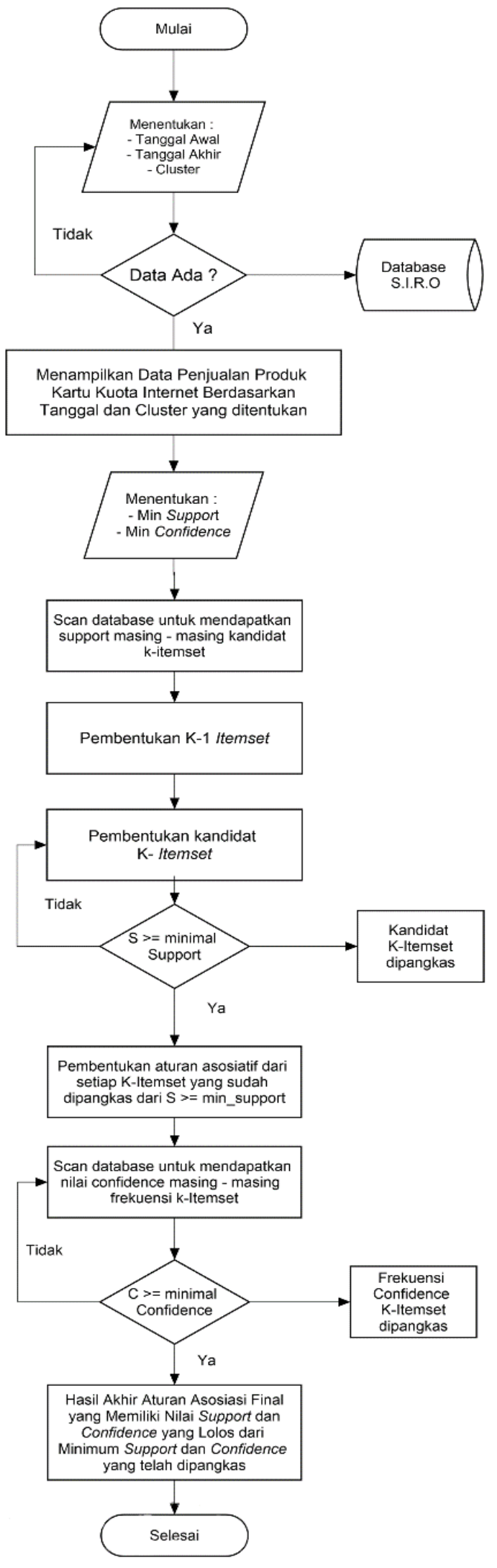

Gambar 2. Flowchart Penerapan Algoritma Apriori 


\subsection{Hasil Implementasi Antarmuka Aplikasi}

Implementasi antar muka ini merupakan aplikasi yang telah selesai dikerjakan sesuai dengan kebutuhan data yang telah dianalisa dan dirancang sebelumnya, serta penerapan metode association rule mining dengan menggunakan perhitungan algoritma apriori dapat dijalankan sebagai kebutuhan supervisor (pimpinan) untuk membantu dalam melakukan analisa terhadap data penjualan produk kartu perdana kuota internet. Gambar 2 dibawah ini merupakan menu utama sales agent.

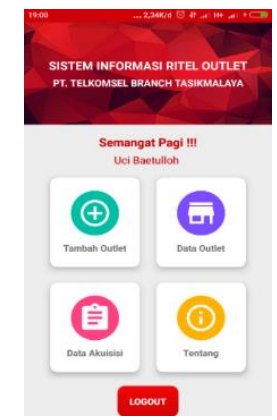

\section{Gambar 3. Halaman Menu Utama Sales Agent}

Pada gambar 3 ini merupakan halaman utama pada aplikasi android yang digunakan oleh sales agent, terdapat beberapa pilihan menu yang dipilih oleh sales agent diantaranya tambah data outlet, lihat data outlet, data akuisisi dan tentang aplikasi. Aplikasi android ini digunakan untuk melakukan pendataan pencapaian penjualan berupa produk kartu perdana kuota internet ke setiap wilayah yang ada di Priangan Timur khususnya wilayah Ciamis, Tasikmalaya dan Garut.

Halaman utama aplikasi merupakan halaman awal pertama kali sistem informasi dibuka setelah admin dan supervisor setelah login berisi informasi dashboard denganpilihan menu navigation yang dimana admin memiliki hak akses sepenuhnya terhadap aplikasi sedangkan supervisor ada beberapa hak akses yang sama dengan admin namun memiliki menu utama untuk menganalisis data menggunakan proses association rule mining dengan perhitungan algoritma apriori. Gambar 4 dan 5 merupakan menu utama akun admin dan supervisor.

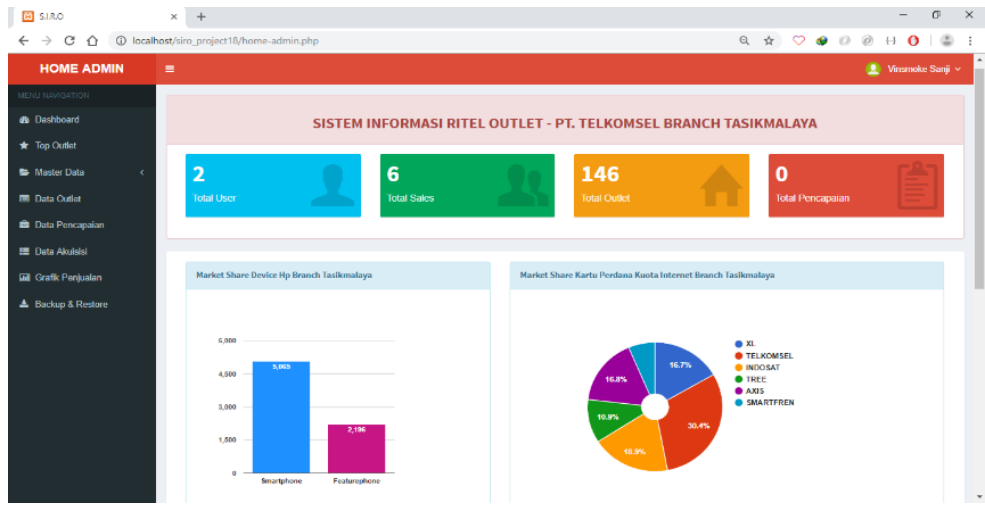

Gambar 4. Halaman Menu Utama Admin

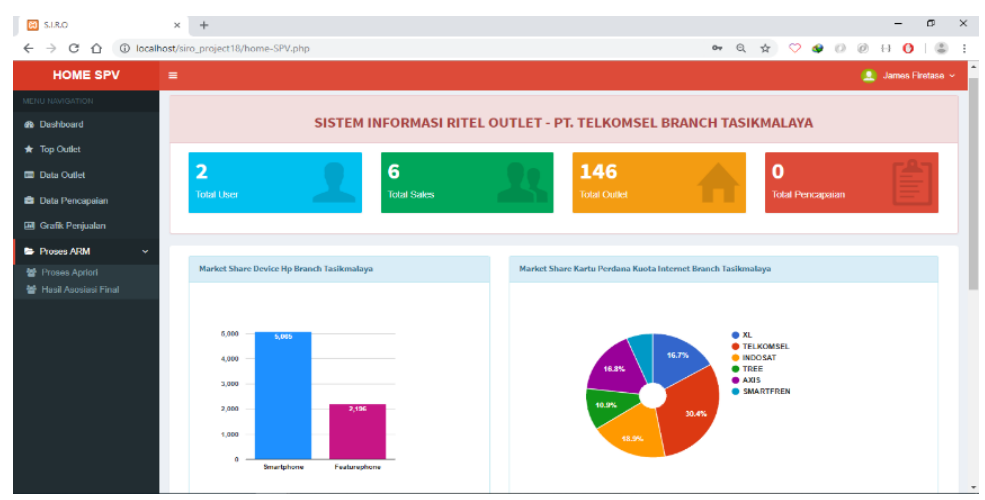

Gambar 5. Halaman Menu Utama Supervisor 
Pada gambar 4 dan 5 merupakan halaman utama sistem informasi ritel outlet berbasias web. Aplikasi web ini digunakan oleh admin dan supervisor. Dimana admin memliki hak akses sepenuhnya terhadap aplikasi, sedangkan supervisor ada beberapa hak akses yang sama dengan admin namun memiliki menu khusus untuk menganalisis data transaksi penjualan menggunakan proses association rule mining dengan perhitungan algoritma apriori.

Akun Supervisor dapat melakukan proses analisa terhadap data transaksi penjualan produk kartu perdana kuota internet, dimana pada proses apriori ini digunakan untuk mencari aturan dasar asosiasi kombinasi item produk mana saja yang paling sering laku terjual jika produk tersebut dikombinasikan dengan produk lainnya. Berikut adalah proses dari penerapan metode asosiasi dengan perhitungan algoritma apriori pada sistem informasi ritel outlet yang tercantum pada gambar 6.

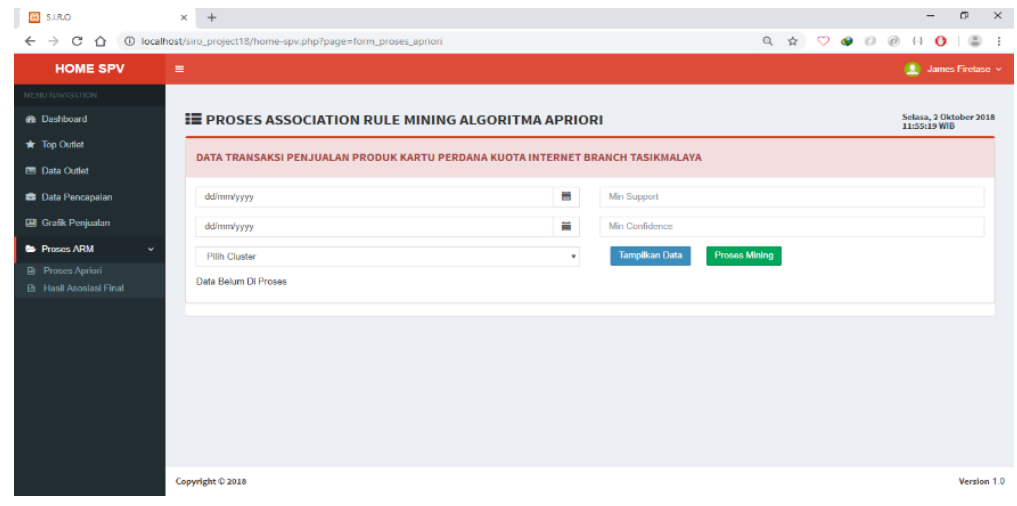

\section{Gambar 6. Halaman Menu Proses Association Rule Mining Algoritma Aprori}

Pada Gambar 6, menunjukan form proses untuk melakukan analisa terhadap data transaksi penjualan produk kartu perdana kuota internet, dimana pada proses apriori ini digunakan untuk mencari aturan dasar asosiasi kombinasi item produk operator mana saja yang paling sering laku terjual jika produk tersebut dikombinasikan dengan produk operator lainnya.

\subsection{Pengujian Implementasi Aturan Asosiasi Perhitungan Algoritma Apriori}

Hasil dan implementasi aturan asosiasi perhitungan algoritma apriori pada sistem yang telah dibangun dapat diuji dan digunakan sebagai proses analisa terhadap data transaksi penjualan produk kartu perdana kuota internet. Sebelum melakukan proses perhitungan apriori, supervisor harus menentukan periode tanggal dan cluster wilayah yang akan dipilih, sebagai contoh periode tanggal yang dipilih dari tangal 01 Maret 2018 sampai 31 Oktober 2018, kemudian menentukan nilai minimum support sebesar 35\% dan nilai minimum confidence sebesar $80 \%$. Gambar 7-15 merupakan tampilan hasil pengujian implementasi aturan asosiasi perhitungan algoritma apriori pada aplikasi.

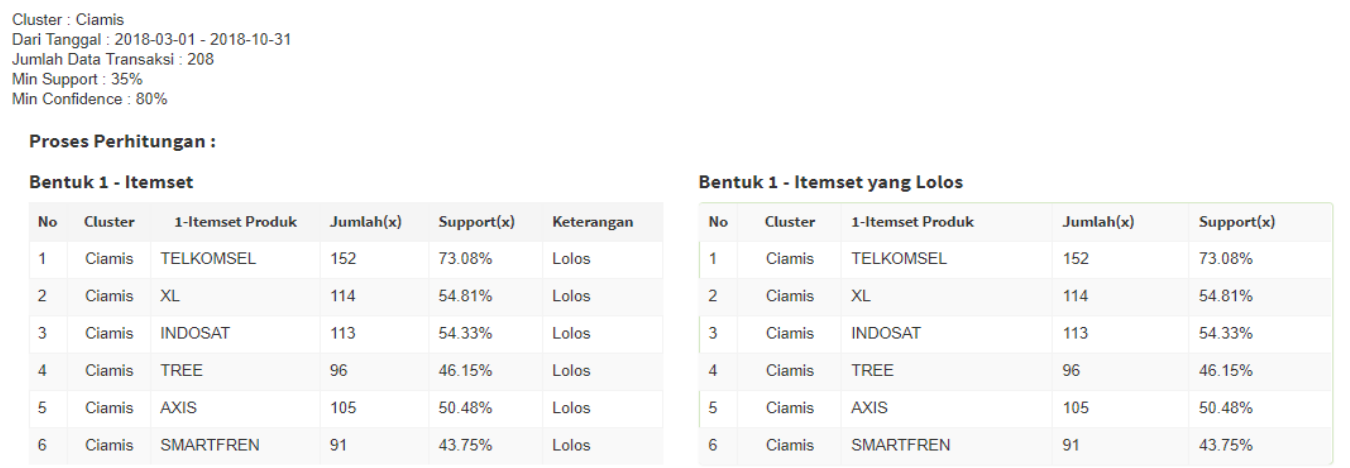

Gambar 7. Halaman Perhitungan Bentuk 1-Itemset Cluster Ciamis

Pada gambar 7, menunjukan proses perhitungan analisa algoritma apriori untuk cluster Ciamis, dimana perhitungan tersebut dilakukan sebanyak 3 iterasi kombinasi itemset pada database, sehingga menghasilkan frekuensi itemset dari setiap iterasi yang telah dilakukan. 


Hasil Aturan Asosiasi Final :
\begin{tabular}{|llllll|}
\hline No & Cluster & Aturan Asosiasi Final & Support & Confidence & Support * Confidence \\
1 & Ciamis & If Sell XL and TREE, Then Sell TELKOMSEL & $35.1 \%$ & $98.65 \%$ & 0.3463 \\
\hline 2 & Ciamis & If Sell TELKOMSEL and TREE, Then Sell XL & $35.1 \%$ & $80.22 \%$ & 0.2816 \\
\hline 3 & Ciamis & If Sell XL and INDOSAT, Then Sell TELKOMSEL & $36.06 \%$ & $94.94 \%$ & 0.3424 \\
4 & Ciamis & If Sell SMARTFREN, Then Sell XL & $35.1 \%$ & $80.22 \%$ & 0.2816 \\
\hline 5 & Ciamis & If Sell SMARTFREN, Then Sell TELKOMSEL & $41.35 \%$ & $94.51 \%$ & 0.3908 \\
\hline 6 & Ciamis & If Sell AXIS, Then Sell TELKOMSEL & $46.15 \%$ & $91.43 \%$ & 0.4219 \\
7 & Ciamis & If Sell TREE, Then Sell TELKOMSEL & $43.75 \%$ & $94.79 \%$ & 0.4147 \\
\hline 8 & Ciamis & If Sell INDOSAT, Then Sell TELKOMSEL & $50.48 \%$ & $92.92 \%$ & 0.4691 \\
\hline 9 & Ciamis & If Sell XL, Then Sell TELKOMSEL & $52.4 \%$ & $95.61 \%$ & 0.501 \\
\hline
\end{tabular}

\section{Gambar 8. Hasil Aturan Asosiasi Final Cluster Ciamis}

Pada gambar 8, menunjukan bahwa terdapat 9 best rules assoctiation final pada cluster Ciamis yang telah melewati tahapan dalam kombinasi dan pemangkasan terhadap setiap itemset dengan menghitung nilai minimum support dan confidence dari proses iterasi pembentukan kandidat 1-itemset, 2-itemset dan 3-itemset. Kemudian menampilkan tiga hasil analisa aturan asosiasi yang memiliki nilai akurasi hasil perkalian dari nilai support dan confidence yang paling tinggi. Dapat dilihat pada gambar 9.

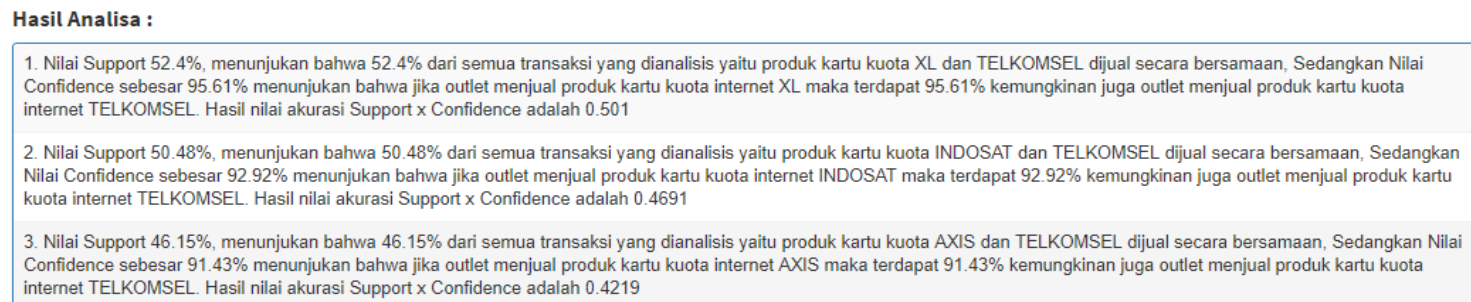

\section{Gambar 9. Hasil Analisa Asscosiation Rules Claster Ciamis}

Pada Gambar 9, analisa aturan asosiasi terbaik dari hasil perkalian support $\mathrm{x}$ confidence adalah 0,501 menunjukan bahwa penjualan produk kartu kuota internet yang paling laku terjual di cluster Ciamis adalah produk operator XL dengan operator Telkomsel. Hal ini menunjukan bahwa kedua operator tersebut memiliki daya saing penjualan yang kuat dengan nilai confidence sebesar 95,61\%.

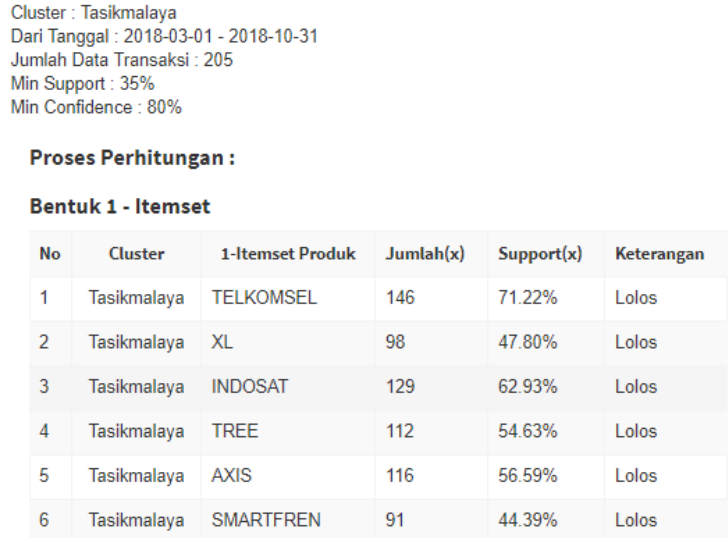

Gambar 10. Halaman Perhitungan Bentuk 1-Itemset Cluster Tasikmalaya

Pada gambar 10, menunjukan proses perhitungan analisa algoritma apriori untuk cluster Tasikmalaya, dimana perhitungan tersebut dilakukan sebanyak 3 iterasi kombinasi itemset pada database, sehingga menghasilkan frekuensi itemset dari setiap iterasi yang telah dilakukan. 


\begin{tabular}{|c|c|c|c|c|c|}
\hline No & Cluster & Aturan Asosiasi Final & Support & Confidence & Support * Confidence \\
\hline 1 & Tasikmalaya & If Sell TREE and AXIS, Then Sell INDOSAT & $38.05 \%$ & $91.76 \%$ & 0.3491 \\
\hline 2 & Tasikmalaya & If Sell INDOSAT and TREE, Then Sell AXIS & $38.05 \%$ & $80.41 \%$ & 0.306 \\
\hline 3 & Tasikmalaya & If Sell TREE and AXIS, Then Sell TELKOMSEL & $38.54 \%$ & $92.94 \%$ & 0.3582 \\
\hline 4 & Tasikmalaya & If Sell INDOSAT and AXIS, Then Sell TELKOMSEL & $44.88 \%$ & $91.09 \%$ & 0.4088 \\
\hline 5 & Tasikmalaya & If Sell TELKOMSEL and AXIS, Then Sell INDOSAT & $44.88 \%$ & $86.79 \%$ & 0.3895 \\
\hline 6 & Tasikmalaya & If Sell INDOSAT and TREE, Then Sell TELKOMSEL & $44.39 \%$ & $93.81 \%$ & 0.4164 \\
\hline 7 & Tasikmalaya & If Sell TELKOMSEL and TREE, Then Sell INDOSAT & $44.39 \%$ & $87.5 \%$ & 0.3884 \\
\hline 8 & Tasikmalaya & If Sell XL and TREE, Then Sell TELKOMSEL & $35.12 \%$ & $96 \%$ & 0.3372 \\
\hline 9 & Tasikmalaya & If Sell XL and INDOSAT, Then Sell TELKOMSEL & $38.54 \%$ & $94.05 \%$ & 0.3625 \\
\hline 10 & Tasikmalaya & If Sell TELKOMSEL and XL, Then Sell INDOSAT & $38.54 \%$ & $86.81 \%$ & 0.3346 \\
\hline 11 & Tasikmalaya & If Sell SMARTFREN, Then Sell TREE & $36.59 \%$ & $82.42 \%$ & 0.3016 \\
\hline 12 & Tasikmalaya & If Sell SMARTFREN, Then Sell INDOSAT & $37.56 \%$ & $84.62 \%$ & 0.3178 \\
\hline 13 & Tasikmalaya & If Sell AXIS, Then Sell INDOSAT & $49.27 \%$ & $87.07 \%$ & 0.429 \\
\hline 14 & Tasikmalaya & If Sell TREE, Then Sell INDOSAT & $47.32 \%$ & $86.61 \%$ & 0.4098 \\
\hline 15 & Tasikmalaya & If Sell XL, Then Sell INDOSAT & $40.98 \%$ & $85.71 \%$ & 0.3512 \\
\hline 16 & Tasikmalaya & If Sell SMARTFREN, Then Sell TELKOMSEL & $40 \%$ & $90.11 \%$ & 0.3604 \\
\hline 17 & Tasikmalaya & If Sell AXIS, Then Sell TELKOMSEL & $51.71 \%$ & $91.38 \%$ & 0.4725 \\
\hline 18 & Tasikmalaya & If Sell TREE, Then Sell TELKOMSEL & $50.73 \%$ & $92.86 \%$ & 0.4711 \\
\hline 19 & Tasikmalaya & If Sell INDOSAT, Then Sell TELKOMSEL & $58.05 \%$ & $92.25 \%$ & 0.5355 \\
\hline 20 & Tasikmalaya & If Sell TELKOMSEL, Then Sell INDOSAT & $58.05 \%$ & $81.51 \%$ & 0.4732 \\
\hline 21 & Tasikmalaya & If Sell XL, Then Sell TELKOMSEL & $44.39 \%$ & $92.86 \%$ & 0.4122 \\
\hline
\end{tabular}

\section{Gambar 11. Hasil Aturan Asosiasi Final Cluster Tasikmalaya}

Pada gambar 11, menunjukan bahwa terdapat 21 best rules assoctiation final pada cluster Tasikmalaya yang telah melewati tahapan dalam kombinasi dan pemangkasan terhadap setiap k-itemset dengan menghitung nilai minimum support dan confidence dari proses iterasi pembentukan kandidat 1itemset, 2-itemset dan 3-itemset. Kemudian menampilkan tiga hasil analisa aturan asosiasi yang memiliki nilai akurasi hasil perkalian dari nilai support dan confidence yang paling tinggi. Dapat dilihat pada gambar 12.

Hasil Analisa :

1. Nilai Support $58.05 \%$, menunjukan bahwa $58.05 \%$ dari semua transaksi yang dianalisis yaitu produk kartu kuota INDOSAT dan TELKOMSEL dijual secara bersamaan, Sedangkan Nilai Confidence sebesar $92.25 \%$ menunjukan bahwa jika outlet menjual produk kartu kuota internet INDOSAT maka terdapat $92.25 \%$ kemungkinan juga outlet menjual produk kartu kuota internet TELKOMSEL. Hasil nilai akurasi Support x Confidence adalah 0.5355

2. Nilai Support $58.05 \%$, menunjukan bahwa $58.05 \%$ dari semua transaksi yang dianalisis yaitu produk kartu kuota TELKOMSEL dan INDOSAT dijual secara bersamaan, Sedangkan Nilai Confidence sebesar $81.51 \%$ menunjukan bahwa jika outlet menjual produk kartu kuota internet TELKOMSEL maka terdapat $81.51 \%$ kemungkinan juga outlet menjual produk kartu kuota internet INDOSAT. Hasil nilai akurasi Support x Confidence adalah 0.4732

3. Nilai Support $51.71 \%$, menunjukan bahwa $51.71 \%$ dari semua transaksi yang dianalisis yaitu produk kartu kuota AXIS dan TELKOMSEL dijual secara bersamaan, Sedangkan Nilai Confidence sebesar $91.38 \%$ menunjukan bahwa jika outlet menjual produk kartu kuota internet AXIS maka terdapat $91.38 \%$ kemungkinan juga outlet menjual produk kartu kuota internet TELKOMSEL. Hasil nilai akurasi Support x Confidence adalah 0.4725

\section{Gambar 12. Hasil Analisa Asscosiation Rules Cluster Tasikmalaya}

Pada Gambar 12, analisa aturan asosiasi terbaik dari hasil perkalian support x confidence adalah 0,5355 menunjukan bahwa penjualan produk kartu kuota internet yang paling laku terjual di cluster Tasikmalaya adalah produk operator Indosat dengan operator Telkomsel. Hal ini menunjukan bahwa kedua operator tersebut memiliki daya saing penjualan yang kuat dengan nilai confidence sebesar 92,25\%. 


\begin{tabular}{|c|c|c|c|c|c|c|c|c|c|c|}
\hline \multicolumn{11}{|c|}{$\begin{array}{l}\text { Cluster : Garut } \\
\text { Dari Tanggal : 2018-03-01 - 2018-10-31 } \\
\text { Jumlah Data Transaksi : } 201 \\
\text { Min Support : } 35 \% \\
\text { Min Confidence : } 80 \%\end{array}$} \\
\hline \multicolumn{11}{|c|}{ Proses Perhitungan : } \\
\hline \multicolumn{6}{|c|}{ Bentuk 1 - Itemset } & \multicolumn{5}{|c|}{ Bentuk 1 - Itemset yang Lolos } \\
\hline No & Cluster & 1-Itemset Produk & $\operatorname{Jumlah}(\mathbf{x})$ & Support(x) & Keterangan & No & Cluster & 1-Itemset Produk & $\operatorname{Jumlah}(\mathbf{x})$ & Support(x) \\
\hline 1 & Garut & TELKOMSEL & 149 & $74.13 \%$ & Lolos & 1 & Garut & TELKOMSEL & 149 & $74.13 \%$ \\
\hline 2 & Garut & $\mathrm{XL}$ & 109 & $54.23 \%$ & Lolos & 2 & Garut & $X \mathrm{X}$ & 109 & $54.23 \%$ \\
\hline 3 & Garut & INDOSAT & 108 & $53.73 \%$ & Lolos & 3 & Garut & INDOSAT & 108 & $53.73 \%$ \\
\hline 4 & Garut & TREE & 95 & $47.26 \%$ & Lolos & 4 & Garut & TREE & 95 & $47.26 \%$ \\
\hline 5 & Garut & AXIS & 110 & $54.73 \%$ & Lolos & 5 & Garut & AXIS & 110 & $54.73 \%$ \\
\hline 6 & Garut & SMARTFREN & 86 & $42.79 \%$ & Lolos & 6 & Garut & SMARTFREN & 86 & $42.79 \%$ \\
\hline
\end{tabular}

Gambar 13. Halaman Perhitungan Bentuk 1-Itemset Cluster Garut

Pada gambar 13, menunjukan proses perhitungan analisa algoritma apriori untuk cluster Garut, dimana perhitungan tersebut dilakukan sebanyak 3 iterasi kombinasi itemset pada database, sehingga menghasilkan frekuensi itemset dari setiap iterasi yang telah dilakukan.

\begin{tabular}{|c|c|c|c|c|c|}
\hline No & Cluster & Aturan Asosiasi Final & Support & Confidence & Support * Confidence \\
\hline 1 & Garut & If Sell XL and AXIS, Then Sell TELKOMSEL & $38.31 \%$ & $97.47 \%$ & 0.3734 \\
\hline 2 & Garut & If Sell XL and INDOSAT, Then Sell TELKOMSEL & $36.32 \%$ & $97.33 \%$ & 0.3535 \\
\hline 3 & Garut & If Sell SMARTFREN, Then Sell TELKOMSEL & $39.3 \%$ & $91.86 \%$ & 0.361 \\
\hline 4 & Garut & If Sell AXIS, Then Sell TELKOMSEL & $51.24 \%$ & $93.64 \%$ & 0.4798 \\
\hline 5 & Garut & If Sell TREE, Then Sell TELKOMSEL & $43.78 \%$ & $92.63 \%$ & 0.4055 \\
\hline 6 & Garut & If Sell INDOSAT, Then Sell TELKOMSEL & $50.25 \%$ & $93.52 \%$ & 0.4699 \\
\hline 7 & Garut & If Sell XL, Then Sell TELKOMSEL & $52.74 \%$ & $97.25 \%$ & 0.5129 \\
\hline
\end{tabular}

\section{Gambar 14. Hasil Aturan Asosiasi Final Cluster Garut}

Pada gambar 14, menunjukan bahwa terdapat 7 best rules assoctiation final pada cluster Garut yang telah melewati tahapan dalam kombinasi dan pemangkasan terhadap setiap k-itemset dengan menghitung nilai minimum support dan confidence dari proses iterasi pembentukan kandidat 1-itemset, 2-itemset dan 3-itemset. Kemudian menampilkan tiga hasil analisa aturan asosiasi yang memiliki nilai akurasi hasil perkalian dari nilai support dan confidence yang paling tinggi. Dapat dilihat pada gambar 15.

Hasil Analisa :

1. Nilai Support $52.74 \%$, menunjukan bahwa $52.74 \%$ dari semua transaksi yang dianalisis yaitu produk kartu kuota XL dan TELKOMSEL dijual secara bersamaan, Sedangkan Nilai
Confidence sebesar $97.25 \%$ menunjukan bahwa jika outlet menjual produk kartu kuota internet XL maka terdapat $97.25 \%$ kemungkinan juga outlet menjual produk kartu kuota
internet TELKOMSEL. Hasil nilai akurasi Support x Confidence adalah 0.5129
2. Nilai Support $51.24 \%$, menunjukan bahwa $51.24 \%$ dari semua transaksi yang dianalisis yaitu produk kartu kuota AXIS dan TELKOMSEL dijual secara bersamaan, Sedangkan Nilai
Confidence sebesar $93.64 \%$ menunjukan bahwa jika outlet menjual produk kartu kuota internet AXIS maka terdapat $93.64 \%$ kemungkinan juga outlet menjual produk kartu kuota
internet TELKOMSEL. Hasil nilai akurasi Support x Confidence adalah 0.4798
3. Nilai Support $50.25 \%$, menunjukan bahwa $50.25 \%$ dari semua transaksi yang dianalisis yaitu produk kartu kuota INDOSAT dan TELKOMSEL dijual secara bersamaan, Sedangkan
Nilai Confidence sebesar $93.52 \%$ menunjukan bahwa jika outlet menjual produk kartu kuota internet INDOSAT maka terdapat $93.52 \%$ kemungkinan juga outlet menjual produk kartu
kuota internet TELKOMSEL. Hasil nilai akurasi Support $x$ Confidence adalah 0.4699

\section{Gambar 15. Hasil Analisa Asscosiation Rules Claster Garut}

Pada Gambar 15, analisa aturan asosiasi terbaik dari hasil perkalian support $\mathrm{x}$ confidence adalah 0,5129 menunjukan bahwa penjualan produk kartu kuota internet yang paling laku terjual di cluster Garut adalah produk operator XL dengan operator Telkomsel. Hal ini menunjukan bahwa kedua operator tersebut memiliki daya saing penjualan yang kuat dengan nilai confidence sebesar $97,25 \%$.

\subsection{Hasil Pengujian}

Berdasarkan hasil pengujian yang telah dilakukan bahwa secara keseluruhan penerapan metode association rule mining menggunakan perhitungan algoritma apriori yang diimplementasikan pada aplikasi web dapat dijalankan dengan baik dan menampilkan informasi hasil analisa aturan asosiastif yang dilakukan oleh sistem sudah sesuai dengan konsep perhitungan algoritma apriori itu sendiri. Hal ini 
tentunya dapat membantu supervisor untuk melalukan analisa terhadap market share penjualan produk kartu kuota internet disetiap pangsa pasar outlet.

\section{KESIMPULAN}

Berdasarkan hasil dan pembahasan pada penelitian yang telah dilakukan, dapat diambil kesimpulan bahwa hasil analisa aturan asosiasi yang terbentuk dari perhitungan algoritma apriori dengan menentukan nilai minimum support 35\% dan nilai minimum confidence $80 \%$, menghasilkan 9 aturan asosiasi final pada cluster Ciamis, dengan aturan asosiasi yang terbaik ditemukan yaitu menunjukan bahwa "Jika outlet menjual produk kartu kuota internet XL, maka ada kemungkinan outlet tersebut menjual produk kartu kuota internet Telkomsel dengan nilai support 52,40\% dan nilai confidence 95,61\% serta nilai akurasi perkalian support dan confidence adalah 0,5010". Kemudian cluster Tasikmalaya memiliki 21 aturan asosiasi final, aturan asosiasi yang terbaik ditemukan yaitu menunjukan bahwa "Jika outlet menjual produk kartu kuota internet Indosat, maka ada kemungkinan outlet tersebut akan menjual produk kartu kuota internet Telkomsel dengan nilai support 58,05\% dan nilai confidence $92,25 \%$ serta nilai akurasi perkalian support dan confidence adalah 0,5355". Terakhir 7 aturan asosiasi final untuk wilayah penjualan Garut, aturan asosiasi yang terbaik ditemukan yaitu menunjukan bahwa "Jika outlet menjual produk kartu kuota internet XL, maka ada kemungkinan outlet tersebut akan menjual produk kartu kuota internet Telkomsel dengan nilai support $52,74 \%$ dan nilai confidence $97,25 \%$ serta nilai akurasi perkalian support dan confidence adalah 0,5129”. Hasil yang diperoleh dalam penelitian ini dapat digunakan untuk membantu proses pengambilan keputusan. Hasil lainnya juga, implementasi ini bisa membantu untuk mengetahui daya saing operator telekomunikasi seluler mana saja yang memiliki tingkat pangsa pasar penjualan yang terbaik di setiap wilayah Priangan Timur.

\section{DAFTAR PUSTAKA}

[1] databoks.katadata.co.id, "Berapa Jumlah Kartu Telepon Seluler yang Beredar?," databoks.katadata.co.id, 2017. [Online]. Available: https://databoks.katadata.co.id/datapublish/2017/10/12/berapa-jumlah-kartu-telepon-seluler-yangberedar.

[2] D. Listriani, A. H. Setyaningrum, and F. E. M. A, "Penerapan Metode Asosiasi Menggunakan Algoritma Apriori pada Aplikasi Analisa Pola Belanja Konsumen ( Studi Kasus Toko Buku Gramedia Bintaro ),” J. Tek. Inform., vol. 9, no. 2, pp. 120-127, 2016.

[3] O. S. A. Destiyati and E. Ariwibowo, "Analisis Perbandingan Algortima Apriori dan Algoritma Hash Based pada Market Basket Analysis di Apotek UAD,” J. Sarj. Tek. Inform., vol. 3, no. 1, pp. 1-10, 2015.

[4] D. Kusumo, M. Bijaksana, and D. Darmantoro, "Data Mining Dengan Algoritma Apriori Pada RDBMS Oracle," J. Penelit. dan Pengemb. Telekomun., 2003.

[5] Ristianingrum and Sulastri, "Implementasi Data Mining Menggunakan Algoritma Apriori," SINTAK, pp. 372-382, 2017.

[6] E. T. L. Kusrini, Algoritma Data Mining. 2009.

[7] J. Han, M. Kamber, and J. Pei, Data Mining: Concepts and Techniques. 2012.

[8] R. S. Pressman, "Rekayasa Perangkat Lunak," in Rekayasa Perangkat Lunak, Andi, Ed. Yogyakarta, 2012.

[9] I. Djamaludin and A. Nursikuwagus, "Analisis Pola Pembelian Konsumen pada Transaksi Penjualan Menggunakan Algoritma Apriori,” SIMETRIS, vol. 8, no. 2, pp. 671-678, 2017.

[10] D. Fitriati, "Implementasi Data Mining untuk Menentukan Kombinasi Media Promosi Barang Berdasarkan Perilaku Pembelian Pelanggan Menggunakan Algoritma Apriori," Annu. Resarch Semin., vol. 2, no. Implementasi Data Mining, pp. 472-480, 2016.

[11] A. Wa. O. Gama, I. K. G. D. Putra, and I. P. A. Bayupati, "Implementasi Algoritma Apriori untuk Menemukan Frequent Itemset dalam Keranjang Belanja,” Tek. Elektro, vol. 15, no. 2, pp. 27-32, 2016. 